\title{
"Uncles' Generation: Adult Male Fans and Alternative Masculinities in South Korean Popular Music (Translation into Russian) ${ }^{1}$
}

\section{Jarryn Ha}

Case Western Reserve University. Cleveland, Ohio, USA. Email: jarryn.ha[at]case.edu

\begin{abstract}
This article discusses the recent emergence of adult male fans of Korean pop (K-pop) music who openly engage themselves in fan activities typically associated with teenagers (particularly teenage girls) and the significance of their adoration of young female celebrities. The recent appearance of the 'samchon/uncle fans' in the K-pop culture discourse marks the first instance since the early 1990s, when teenagers became the primary target audience of South Korea's entertainment industry, in which male adults reclaimed a significant position as a demographic group of fans. The samchon fans differ from the traditional ajossi (middle-aged, patriarchal men) listeners of adult contemporary music in the kinds of singers and musical genres to which they listen, as well as in their self-identification as fans, participation in fan activities and mass media portrayals. I investigate the implications of the men's consumption pattern and their representation in South Korean mass media within the contexts of the history of the construction of hegemonic masculinity in South Korea and of recent developments in East Asian popular culture. I also explore possible ways to apply, complicate and question existing theoretical and conceptual frameworks to explain the phenomenon and argue for the possibility of politically potent, alternative masculinities constructed and manifested through the men's conspicuous consumption of cultural commodities.
\end{abstract}

\section{Keywords}

Korean Pop; Masculinity; Adulthood; Grass-Eating Men; Conspicuous consumption; Habitus

This work is licensed under a Creative Commons «Attribution» 4.0 International License

1 We are grateful to the author and the editors of the Journal of Fandom Studies for permission to translate and publish the article Ha, J. (2015), Uncles generation: Adult male fans and alternative masculinities in South Korean popular music. Journal of Fandom Studies, 3(1), 43-58. https://doi.org/10.1386/jfs.3.1.43_1 


\section{Поколение дядюшек: взрослые фанаты- мужчины и альтернативная маскулинность в южнокорейской популярной музыке (перевод на русский) ${ }^{1}$}

\section{Ха Джаррин}

Университет Кейс Вестерн Резерв. Кливленд, Огайо, США. Email: jarryn.ha[at]case.edu

\section{Аннотация}

В данной статье рассматривается сравнительно новое явление - взрослые фанаты корейской поп-музыки (К-поп) мужского пола, которые открыто участвуют в фанатской деятельности, обычно ассоциирующейся с подростками (в особенности с девочками-подростками); оцениваются следствия их увлечения молодыми знаменитостями женского пола. В начале 1990-х годов подростки стали основной целевой аудиторией южнокорейской индустрии развлечений, и недавнее появление «фанатов самчхон / дядюшек» в дискурсе К-поп культуры знаменует собой первый случай возвращения взрослым мужчинам значительной демографической роли в фанатской группе. Фанаты самчхон отличаются от традиционных аджосси (патриархальных мужчин среднего возраста), слушающих современную «взрослую» музыку, интересом к иным типам исполнителей и музыкальным жанрам, а также их самоидентификацией в качестве фанатов, участием в фанатской деятельности и изображением в средствах массовой информации. Исследуется воздействие мужской модели потребления и их репрезентации в южнокорейских масс-медиа в контексте истории формирования гегемонной маскулинности и последних событий в популярной культуре Восточной Азии. Кроме того, исследуются возможные способы применения, усложнения и оспаривания существующих теоретических и концептуальных рамок для объяснения этого явления и утверждается возможность политически мощных, альтернативных маскулинностей, конструируемых и проявляющихся через демонстративное потребление мужчинами культурных продуктов.

\section{Ключевые слова}

корейская поп-музыка; мужественность; взрослая жизнь; травоядные мужчины; демонстративное потребление; габитус

Это произведение доступно по лицензии Creative Commons «Attribution» («Атрибуция») 4.0 Всемирная

1 Мы выражаем признательность автору, Джаррин Ха, и редакции Journal of Fandom Studies за разрешение на перевод и публикацию статьи На, J. (2015), 'Uncles' generation: Adult male fans and alternative masculinities in South Korean popular music'. Journal of Fandom Studies, 3(1), 43-58. https://doi.org/10.1386/jfs.3.1.43_1 


\section{Вступление}

На протяжении большей части 1990-х годов и первого десятилетия XXI века потребительская база фанатов южнокорейской поп-музыки состояла в основном из подростков. Жизнерадостная подростковая поп-музыка, выпускаемая крупными звукозаписывающими лейблами, сменила современную музыку для взрослых, начала доминировать в национальной популярной культуре. Подростки, обладающие возросшей покупательной способностью, практически оттеснили предыдущее поколение на задворки; стал очевиден разрыв между поколениями в культурном потреблении. Однако в последние несколько лет южнокорейские СМИ сообщают о растущем числе взрослых мужчин, в основном за 30, которые открыто следят за молодыми айдолами женского пола и активно участвуют в фан-группах и мероприятиях, сглаживая различия в мировоззрении младших и старших. Эти мужчины, именуемые поклонниками самчхон / дядями, похоже, конструируют отдельную идентичность-габитус и, вероятно, даже новую модель маскулинности, бросая вызов широко распространенному стереотипу «аджосси» - мужчины среднего возраста, который долгое время ассоциировался с «правильной» корейской маскулинностью патриархального «белого воротничка». На феномен стоит обратить пристальное внимание, поскольку он свидетельствует о существовании (или, по крайней мере, возможности) альтернативных маскулинностей как среди знаменитостей, так и среди обычных людей. Если согласиться с идеей о возможности и легитимности конструирования идентичности посредством демонстративного потребления благ, становится ясно, что необходимо обратить наш исследовательский интерес на мужчин, которые одержимы видом превращенных в товар поп-звезд, относящихся к другой демографической группе, и которые делают все, чтобы это различие было увековечено.

Результаты неоднозначные. С одной стороны, такие фанаты отражают потребление корейской поп-музыки (К-поп) в широком спектре стилей и поджанров. Они нарушают установившийся баланс между легитимным и нелегитимным, легко потребляемым искусством и низкопробным, взрослым и подростковым, мужественным и женственным. Последнее казалось стабильным довольно долгое время, о чем свидетельствуют разнообразные поджанры корейской популярной музыки и аудитория, которую каждый из них привлекал. С другой стороны, рост числа самчхон-фанатов является своеобразным коллективным комментарием на тему преобладающей в Южной Корее маскулинности и ожиданий, которые общество возлагает на мужчин. Комментарий этот в основном принимает форму демонстративного потребления товаров, которые обычно считаются «немужскими» или неприемлемыми для мужского потребления, что бросает вызов существующим представлениям о гендерных ролях и правильных моделях потребления. Целью данной статьи 
является рассмотрение альтернативных путей маскулинности, предложенных самчхон-фанатами, и оценка значения указанного феномена.

В послевоенные десятилетия на южнокорейской сцене в основном доминировал поджанр музыки для взрослых под названием «трот», черты которого включают двухдольный ритм, минорный лад, оркестровый аккомпанемент (реальный или на синтезаторе), а также интенсивные вокальные модуляции и орнаментации. В конце 1980 - начале 1990-х годов трот постепенно отступил на задний план, став локализованным и традиционным жанром, а доминирующее положение в мейнстриме страны заняли любовные баллады и подростковый поп (Pak, 2006, p. 64-66; Son 2006, p. 51). На экономическом уровне этот сдвиг в доминирующем музыкальном стиле совпал с почти одновременным сдвигом в господствующей бизнес-модели корейской популярной музыки. Во время финансового кризиса, поразившего Корею и соседние регионы в конце 1990-х годов, многие звукозаписывающие лейблы, играющие заметную роль на внутреннем рынке, не были организованы как крупномасштабная экономическая сила. Они столкнулись с финансовыми трудностями, которые вынудили резко сократить штат или, что еще хуже, полностью выйти из бизнеса. Заполнили пустующие места в индустрии управляющие компании, которые предпочитали гораздо более интегрированный подход к производству культурных товаров, продвигая итоговые продукты (в отличие от просто записей) в основном на рынок наиболее мощной и относительно неосвоенной демографической группы: подростков.

Все более системная и зрелищная индустрия развлечений принесла славу юным исполнителям с «молодым» стилем. Их музыка, более продуманная и более коммерциализованная, чем у большинства современных взрослых исполнителей, вскоре затмила последних на рынке, и подростки с выросшей покупательской способностью (благодаря бурно развивающейся экономике страны к началу 1990-х гг.) стали лидировать в потреблении корейской попмузыки. Ориентированные на взрослых музыкальные стили (как трот) не исчезли со сцены, остались и их преданные поклонники. Однако они остались на задворках рынка, а приоритетное место заняла музыка для более молодых потребителей. Это позволило осуществлять систематический менеджмент, маркетинг исполнителей и перформативных товаров в таких формах, как визуально стимулирующие постановки телевизионных выступлений, эффектные музыкальные видеоклипы с участием известных актеров, крупномасштабные концерты, телешоу, в которых многочисленных музыкантов побуждали и зачастую даже заставляли появляться, и товары с изображением исполнителей. Это направление корейской популярной музыки, в значительной степени разработанное и продаваемое конгломератами индустрии развлечений, в конечном итоге стало первым брендом К-рор, вышедшим за пределы Корейского полуострова. Резкое расширение рынка К-рор сегодня называется «корейской волной» (или Hallyu). 


\section{Методология}

Поскольку данная статья посвящена современной южнокорейской популярной культуре, мой подход носит теоретический характер. Я обозначаю закономерность (довольно последовательное вовлечение взрослых мужчин в музыкальные фандомы К-рор, которые в прошлом ассоциировались в основном с девочками-подростками), применяя существующие идеи и концептуальные рамки для объяснения и осмысления этого явления. Теоретические модели сопровождаются и дополняются эмпирическими наблюдениями за музыкальными программами на южнокорейском телевидении, а также за деятельностью фанатов на веб-форумах, взаимодействием с присутствующими на концертных мероприятиях. Более того, будучи уроженцем Кореи, я полагаюсь на свои знания истории и культуры страны и на свое понимание идеалов и ожиданий, разделяемых или оспариваемых ее жителями, чтобы вписать свой анализ в соответствующий культурный контекст. Мое понимание культуры изнутри ценно как основа для суждений о том, какие аспекты рассматриваемого явления становятся значимыми и почему. Тем не менее, есть несколько моментов, которые я обсуждаю в этой статье лишь вкратце или вовсе опускаю, не обязательно потому, что они менее значимы, но скорее в силу отсутствия необходимых для анализа данных, интервью и этнографических исследований. И наконец, все неатрибутированные переводы корейских текстов принадлежат автору статьи.

\section{Быть фанатом}

Кто такие фанаты и чем они занимаются? Они могут слушать музыку артиста, который является их кумиром, коллекционировать его альбомы, синглы, плакаты и другую атрибутику, смотреть телевизионные программы, в которых появляется объект увлечения, создавать произведения искусства и литературы, вдохновленные им, следить за рекламными акциями и посещать «живые» выступления (и другие публичные мероприятия). Наиболее заметными для широкой публики из этих видов фанатской деятельности являются открытое и коллективное отслеживание промо-акций кумира и публичных живых выступлений. Давно стало обычным явлением для больших фан-групп (в основном подростков) разбивать лагерь у офисов управляющих компаний, телевизионных студий и квартир исполнителей (особенно это касается молодых айдол-групп, которым менеджмент лейбла часто предоставляет совместное жилье), в надежде мельком увидеть своих кумиров. Любопытно, что превращение телевидения в основное средство распространения музыки, по сути, привело к переносу центра фанатской активности из домов в общественные места (т.е. телевизионные студии и концертные площадки). Хотя, возможно, частью маркетинговой стратегии развлекательных компаний было организация масштабных зрелищ с участием толп зрителей, этот новый, 
очень демонстративный и отнимающий много времени способ потребления, безусловно, является более подходящим вариантом для молодежи, а не для взрослых с регулярной работой с девяти до пяти. Возникновение такого рода активного, инициативного способа быть фанатом в Южной Корее знаменует собой проникновение андеграундной (и часто патологизированной) фандомной культуры в капитализированный мейнстрим. Но даже при всем этом в большинстве своем подростковая демографическая группа новых возникающих фандомов и их типичная деятельность, требующая большого количества времени и самоотдачи, вероятно, стали причиной маркировки таких фанатов как «ненормальных», «незрелых» или «Других». Как пишет Джоли Дженсон, сравнивая увлеченность и фанатство:

\begin{abstract}
Что если мы опишем приверженность, которую ученые испытывают к академическим дисциплинам, а не к командным видам спорта, и посещение научных конференций, а не концертов и футбольных матчей? [...] Будут ли здесь применяться стереотипы о неадекватности, девиантности и опасности? Вероятно, нет. [...] Кажется, что фандом трудно представить как некую базовую или общую черту, как форму лояльности или привязанности, как способ "принятой близости". Вместо этого фандом - это то, что делают “Они", а "Мы", с другой стороны, обладаем вкусом и предпочтениями, и отдаем свое уважение и восхищение достойным людям, убеждениям и занятиям. Более того, то, что делают "они", является девиантным, а значит, опасным, а то, что делаем "мы", является нормальным, а значит, безопасным (1992, р. 19).
\end{abstract}

Фанат корейской популярной музыки в этом контексте вдвойне ненормален, в силу возраста и патологического статуса фандома и его деятельности. Подростковая демографическая группа фандома К-поп работает на его «Инаковость», что связано с незрелостью, нестабильностью и фундаментальным недостатком (определяемым в негативных терминах, т.е. как неспособность быть надлежащим взрослым), связанным с возрастной группой.

Конечно, появление подростков-фанатов поп-музыки - это не первый случай в истории, когда молодежная культура считалась ненормальной. Известный пример такого рода высказываний можно найти в тексте Дика Хебдиджа 1979 года о молодежных субкультурах. Описываемые им британские субкультуры создают и манифестируют последовательные, многомерные системы посредством «нарушения дозволенных кодов, с помощью которых социальный мир организуется и переживается» и «выражения запрещенного смысла (осознание класса или отличий) в запрещенных формах (нарушение вестиментарных и поведенческих норм, попрание закона и т.д.)», которые с точки зрения доминирующей культуры являются «неестественными» (Hebdige, 1979, p. 91-92). Эти субкультуры также используют существующие материальные коды в качестве строительного материала для своего выражения, в процессе конструирования смысла через использование конкретных символов, что Хебдидж называет «бриколажем» (1979, р. 102-104). Однако поколение поклонников южнокорейской популярной музыки после 1990-х годов отличается тем, что их демонстративное потребление едва ли 
напоминает идеологическую оппозицию гегемонии, если вообще таковая имеется. Патологизация этой культуры, другими словами, основывается на «чрезмерном» увлечении и преданности объектам привязанности и вытекающей из этого неспособности участвовать в деятельности, которой должны заниматься «нормальные» граждане капиталистической экономики. Вместо вкуса или предпочтений они демонстрируют одержимость; подразумевается, что что-то в них и в том, что они делают, неправильно.

\section{Быть мужчиной}

Участие взрослых мужчин в музыкальных фандомах К-рор усложняет различие или политическое разделение между двумя культурными классами. Существующая динамика среди «нормальных» и «ненормальных» изменяется в основном двумя способами. Во-первых, деятельность и проявление идентичности, которые обычно ассоциируются с бесправными (в патриархальном обществе), теперь перенимаются сильными. В этом контексте принятие мужчинами фан-идентичности через демонстративное потребление музыкальных товаров, похоже, не опровергает ни статус доминирующей группы, ни принадлежность фан-культуры к периферии культурной политики, а скорее приводит к появлению альтернативной маскулинности, которая заслуживает пристального внимания. Во-вторых, таким образом они пытаются отвергнуть стереотипы и отойти от ожидаемой от них традиционной модели маскулинности. Эта функциональная, стилистическая и телеологическая модель для южнокорейских мужчин воплощена в «аджосси»- слове, которое в самом узком смысле означает «дядя», но эволюционировало до обозначения любого взрослого мужчины, поскольку в корейском языке термины родства часто распространяются на незнакомых людей. Характеристика «аджосси» влияет не только на ожидаемый от мужчин внешний облик, но и на их поведение, модель потребления и идеологию, которая формирует и закрепляет особый тип маскулинности, исторически сложившийся в корейском обществе. Устойчивые конфуцианские патриархальные ценности и ставший нормой после быстрой модернизации, индустриализации страны во второй половине XX века идеал мужчины-трудоголика способствовали формированию традиционной маскулинности аджосси. Аналогичный случай можно найти в японском образе сараримана (т.е. белого воротничка), который также отражает «навязанные корпоративные маскулинные идеалы и ожидания» (Iida, 2005, p.63).

В стране, где 40-часовая рабочая неделя стала нормой только в середине 2000-х годов и где работники проводят на работе больше времени, чем в любой другой стране-члене Организации экономического сотрудничества и развития (ОЭСР), ответственность за обеспечение семьи -тяжким трудом часто ложится в основном на мужчин, несмотря на рост числа работающих полный рабочий день женщин (Министерство стратегии и финансов 2012, 9). 
В результате мужчины, тратящие время и деньги на досуг или культурные мероприятия, часто ассоциируются с экстравагантностью и пренебрежением обязанностями достойного, продуктивного гражданина (и неспособностью соответствовать идеалу последнего), что видно из изображения в СМИ так называемых твенджаннам (doenjangnam, «соевых мужчин»), мужского аналога твенджаннё, уничижительного стереотипа в отношении женщин, которые тратят большие суммы денег на дорогую еду и аксессуары (Pearson and Rashid, 2012).

Согласно преобладающей гендерной норме, корейские мужчины не должны тратить деньги и время на досуг, хобби или культурные блага, такие как посещение концертов и уход за собой. Однако в последние годы наблюдаются отклонения и отступления от этой нормы. С одной стороны, южнокорейские актеры и певцы все чаще стали придерживаться метросексуального стиля, что, возможно, является отражением масштабной тенденции среди корейских мужчин тратить все больше денег и времени на культивирование и поддержание стильного, ухоженного и элегантного внешнего вида. Хотя такую тенденцию часто называют «феминизированной мужественностью» (Iida 2005: 56), считать эстетическое восприятие исключительно женским было бы ошибочно. Подобная чувствительность и внимание к внешнему виду и самопрезентации ассоциируются с женственностью во многих культурах, включая современную Южную Корею, но в эстетическом сознании мало что является женским по своей сути. Вместе с тем, эта тенденция, безусловно, отходит от общепринятой модели современной корейской мужественности, выраженной «аджосси». Хотя такие различия в подходах к выражению мужественности между поколениями редко становятся главной темой в телевизионных драмах и других продуктах СМИ, посвященных конфликту поколений, мужчины разных возрастов явно различаются по манере одеваться и держать себя на публике и на экране.

С другой стороны, такой поколенческий разрыв в идеалах маскулинности типичен для южнокорейских мужчин в целом; ключевым фактором вновь становится потребление. Косметическая промышленность и индустрия моды, традиционно нацеленные в основном на женскую аудиторию, быстро отреагировали на появление нового, эстетически ориентированного идеала мужчины, создав многочисленные линии продукции и бренды, рассчитанные исключительно на мужчин, отдающих предпочтение «мужским предметам красоты» (Miller, 2006, p. 125). Все чаще молодые корейцы уходят из мужских парикмахерских в салоны красоты, которые раньше считались исключительно женской территорией. Создавая иной образ маскулинности и конструируя новый набор поколенческих идеалов через потребление благ, через принятие модели потребления, которая кардинально отличается от модели потребления типичного мужчины предыдущего поколения, эти мужчины бросают вызов существующему социальному порядку. Хотя типичные дискуссии об изменении и диверсификации маскулинности в современной Корее редко фокусируются 
на власти, основной вопрос гораздо более фундаментальный и сложный, чем просто индивидуальные вкусы.

\section{Что на кону?}

Дело не просто в привычках потребления отдельных людей или групп, а в том, что французский социолог Пьер Бурдье называет «габитусом» - объективной гомогенизацией практик «без какого-либо намеренного расчета или сознательной ссылки на норму [...] взаимно согласованных в условиях отсуmствия прямого взаимодействия или, a fortiori, явного со-управления» (1977, p. 80, оригинальный курсив). Другими словами, понятие габитуса подразумевает подсознательную идеологическую конструкцию, которая связывает социальную структуру и составляющие общества без намеренной синхронизации. Указанный конструкт в конечном итоге определяет культурные предпочтения и вкусы индивидов, а не лежащие в основе (и давно существующие) социальные факторы, которые порождают эти тенденции. В связи с этим в остальной части статьи будет описано, как концепция габитуса может помочь объяснить рост числа самчхон-фанатов и как влияние социальных факторов усложняет наше понимание культурных преференций. Выбор мужчинами модели потребления и приоритетов (т.е. их преданность интересам за пределами традиционно мужских сфер работы и семьи), следовательно, является политически значимым актом. И я интерпретирую участие самчхон-фанатов в фандомах поп-музыки именно в контексте отступления корейских мужчин от нормативной, патриархальной формы укоренившейся в национальной культуре маскулинности.

Участие мужчин в фан-культуре было довольно «скрытым», предположительно из-за их основных обязанностей как глав семей, сыновей, работников и так далее. Тем не менее, существуют три вида свидетельствующих о происходящем источников, относительно свободных от культурного давления: мужская активность на веб-сайтах и дискуссионных онлайн-площадках, освещение фанатской активности мужчин в СМИ (особенно на телевидении) и знаменитости, которые открыто признают и обсуждают свою увлеченность более молодыми женщинам-идолам. Беглого взгляда на сообщения и комментарии на таких сайтах, как DC Inside, Daum и Twitter, достаточно, чтобы понять, что сам ярлык «самчхон» используется как взрослыми мужчинами-фанатами, так и сторонними наблюдателями. Они также в основном занимаются деятельностью, которая мало мешает их обычным дневным обязанностям, например, следят за своими любимыми исполнителями в социальных сетях, размещают и распространяют в Интернете материалы об исполнителях и по возможности посещают их концерты. О ночевках возле корпоративного офиса компании или квартиры идол-группы обычно не может быть и речи. Посещение концертов и телевизионных съемок музыкальных программ (обычно с участием живой аудитории в студии), гораздо более приемлемо для работающих людей. 
Все чаще можно увидеть взрослых мужчин-фанатов на этих мероприятиях, а также на эфирной версии программ (что говорит о множестве сознательных решений в процессе производства), заметно возбужденных и воодушевленных посещением мероприятий и встречей со своими любимыми звездамиидолами. Мысль, что мужское поведение - это не просто акт праздности, а скорее политическое заявление, подтверждается (и отчасти обосновывается) замечанием одного из таких фанатов, 32-летнего Ёнгиля из Инчхона, которого я встретил на телевизионной съемке в студии Корейской вещательной системы (KBS). Ожидая очереди на вход в студию, он сказал:

«Все более открытое и заметное участие в фандоме [его и других поклонников] ... делает заявление о культуре, которая ценит исключительно трудолюбивую, самоотверженную патриархальную фигуру, остающуюся умышленно невежественной в отношении таких якобы ничтожных и тривиальных вещей, как музыка и другие формы искусства и культуры».

«Патриархальные гендерные установки мешают мужчинам чувствовать себя комфортно», - добавляет его 29-летняя невеста Нараэ, делая «что-то настолько естественное, как сказать, что тебе нравится музыкант и его музыка, чем-то ненормальным и патологическим, чего нужно стыдиться». Вызов существующему положению вещей не оправдывается возвышенными целями общественного движения, но определяется правом человека принимать свои увлечения. В Южной Корее в наше время оспаривание культурных установок и стереотипов происходит все чаще. Отчасти это происходит из-за вовлечения в процесс взрослых мужчин, которые занимают социальное положение, позволяющее им инициировать импульс, необходимый для рождения заметного социального движения и перемен, а также из-за того, что индустрия культуры и те, кто вовлечен в работу СМИ, предоставляют больше места для «неортодоксальной» аудитории, усиливая ее голос. Знаменитости открыто говорят о своих увлечениях как фанаты, они могут показать гораздо более ясную и многогранную перспективу, поскольку большинство их высказываний массово транслируются по телевидению, радио и в социальных сетях. Их слова нельзя рассматривать так же, как комментарии обывателей, поскольку в круг интенций включаются поддержание экранного имиджа, определенной манеры поведения; при этом знаменитости нацелены на избежание любого потенциального скандала.

Ночные телевизионные программы популярны во многих странах, и хотя их форматы и жанры могут различаться, большинство из них включают музыкальные выступления. Гораздо реже встречаются коммерческие программы, в которых особое внимание уделяется именно живому исполнению. Однако поздние ночные музыкальные программы не только распространены, но и довольно популярны в Южной Корее, где телевизионные станции транслируют их на национальном уровне уже несколько десятилетий. Одним из ранних примеров такого формата является «Маленький концерт Но Ён Шим» (Noh Young Shim-eui Jageun Eumakhoe / Noh Young Shim's Little Concert), транс- 
лировавшийся на национальном канале KBS с 1992 по 1994 год. Все три эфирные телевизионные сети, вещающие на национальном уровне в Южной Kopee, KBS, Munhwa Broadcasting Corporation (MBC) и Seoul Broadcasting System (SBS), подготовили и выпустили в эфир ряд таких музыкальных передач. В настоящее время в эфире находятся программы «Концерт 7080» и «Альбом этюдов Ю Хиёля». Первая выходит на национальном канале KBS-1TV по воскресеньям вечером, ее ведет Пэ Чхоль Су, опытный 60-летний радиоведущий и диджей. Как следует из названия, в программе в основном участвуют певцы, которые пользовались коммерческим успехом в 1970-х и 1980-х годах, что привлекает студийную аудиторию (и, предположительно, телезрителей) в возрасте от 40 лет и старше.

«Альбом эскизов Ю Хиёля» (Yu Huiyeol's Sketchbook), впервые вышедший в эфир в 2009 году на канале KBS-2TV, судя по примерному возрастному диапазону студийной аудитории, привлекает в основном молодых зрителей. Каждый эпизод длится 80 минут без рекламных пауз и состоит из 15-20 минутных выступлений трех-пяти исполнителей на сцене, установленной в телевизионной студии и напоминающей концертную площадку. Автор песен и продюсер Ю Хиёль ведет передачу, он представляет и кратко интервьюирует каждого исполнителя, но приоритет остается за выступлениями, а не разговорами. Программа Ю, как и многие подобные, отражает личность ведущего и его музыкальный вкус. Например, The Sketchbook показывает огромное количество независимых музыкантов, отдавая особое предпочтение тем, кто специализируется электронике и сибуя-кей${ }^{1}$, продолжая тенденцию, заложенную ведущим в его прошлых радиопередачах, таких как «Вся эта музыка» (2002-2004) и «Радио Чонгук / Радио Небеса» (2008-2011). В качестве постоянных гостей в программе также выступают знакомые ведущего, которые имели с ним тесные музыкальные связи. Из 215 эпизодов, выходивших в эфир с апреля 2009 года по декабрь 2012 года, Lucid Fall появился в восемнадцати, Сон Ши Кён - в шестнадцати, Ким Ён У - в двенадцати, а Юн Чон Син, Ким Чан Хун и Ли Джок - в девяти. Большинство из этих исполнителей сотрудничали с Ю в прошлых музыкальных проектах, выступали с ним в радиопрограммах или подписаны на лейбл Ю, Antenna Music и публично сообщали о близких личных отношениях с ним. Такая субъективность вносит свой вклад в подчеркнуто личную атмосферу шоу и способствует видимому «разрушению образа».

На мой взгляд, программа The Sketchbook интересна тем, что в ней довольно часто появляются группы девушек-идолов и молодых музыканток, которых мало ожидаешь встретить в подобной передаче и которые не связаны с ведущим. Во многих случаях единственным объяснением их появления служат восторженные заявления Ю во время интервью, достаточно убедительные благодаря личностным смыслам, пронизывающим программу, и открытости Ю в выражении симпатии к ряду женщин-музыкантов

1 Разновидность японской поп-музыки (прим. переводчика) 
в интервью и личных беседах на телевидении, радио и в Интернете. B частности, певица IU (Ли Чжи Ын) впервые появилась в эпизоде The Sketchbook от 3 июля 2009 года, в котором крупным планом была запечатлена довольная ухмылка Ю на фоне импровизированного выступления 16-летней певицы во время интервью. Телезрители и поклонники сразу после трансляции начали распространять в Интернете фотографии и видеофрагменты реакции Ю, придумав такие термины, как «Mae-eui nun» («ястребиный глаз») и «Heergasm», последний из которых представляет собой сочетание фамилии Ю и слова «оргазм» (Park, 2011). Также в эпизоде The Sketchbook (2012) от 15 сентября 2012 года Ю представил группу KARA как «женщин, которые сделали возможным лучший момент в [его] жизни», и это суждение он неоднократно подтверждал в других эпизодах. Мужчины в студии с энтузиазмом встречали исполнительниц, о чем можно судить по кадрам, вышедшим в эфир. В большинстве эпизодов музыкальных программ, в том числе и в The Sketchbook, где выступают группы девушек и молодые исполнительницы, взрослые мужчины-фанаты показаны в диком восторге, бурно аплодирующими. Во всех (кроме двух) выпусках с-молодыми исполнительницами в программе The Sketchbook, выходивших в эфир с июня по ноябрь 2013 года, крупным планом представлены рукоплещущие мужчины в зале, в то время как вступления других артистов редко монтировались подобным образом. По всей видимости, продюсеры программы стремились показать мужчин-фанатов, восхищающихся молодыми женщинами, и тем самым угодить этой демографической группе. Важно также отметить, что подобные решения, сделанные в процессе производства, служат для легитимизации как музыки айдолов, так и одержимости ею взрослыми фанатами, перенося их из мира ориентированных на подростков программ прайм-тайм в мир чуть более «приличных» ночных музыкальных программ.

Деятельность поклонников самчхон выходит далеко за рамки посещения телестудий. Обычно эти мероприятия называют «ореu» (термин происходит от сокращенной формы слова «offline» ${ }^{1}$, личные встречи фанатов варьируются от собраний, спонсируемых менеджментом айдолов, до неформальных вечеринок, организуемых фанатскими группами. Судя по посетителям этих мероприятий, многие группы девушек-идолов привлекают большое количество взрослых мужчин-фанатов. Одним из примеров является группа Crayon Pop, состоящая из пяти человек. Самчхон группы неофициально называются «попджосси», что является производным от «поп» (из названия группы) и «аджосси». Многие «попджосси» также являются членами Sketchbook, официального фан-клуба группы, организованного ее лейблом, но их деятельность выходит далеко за рамки последнего. Взрослые мужчины-фанаты Crayon Pop организуют массовые закупки толстовок, свитшотов и блондинистых париков, сделанных на заказ и напоминающих сценические костюмы группы, и посе-

1 Речь идет о корейском чтении этого слова (прим. переводчика) 
щают мероприятия opeu в этих нарядах. Более того, некоторые группы фанатов даже снимают на видео свое исполнение танцевального номера с сингла Bar Bar Bar и размещают видео на сайтах вроде YouTube (примеры можно найти на каналах YouTube пользователей Kim701006 и dunungbaba, среди прочих). В статье, опубликованной в журнале Тime, один из поклонников Crayon Рор утверждает, что самчхон-фанат думает об исполнительнице «как дядя, который смотрит на племянницу, интересуясь ее активностью, и поддерживает» (Rothman 2013), стремясь оформить дискурс о самчхон в совершенно ином контексте, нежели это присуще молодым людям, воспринимающим айдолов через призму романтики и сексуальности. Однако, хотя заявление вышеупомянутого поклонника подкрепляется менее сексуализированным и более непринужденным имиджем девичьей группы, не все исполнительницы, у которых есть такие фанаты, позиционируют себя подобным образом.

\section{О чем это говорит?}

Один из вариантов объяснения мужской одержимости молодыми женщинами-знаменитостями - это отнюдь не новое воплощение традиционного мужского желания покорять, доминировать и обладать женщинами как объектами. С этой точки зрения, появление поклонников самчхон представляет собой возвращение зрелым мужчинами доминирующего положения, оно гораздо мощнее, чем подростковая одержимость, из-за возрастных и, во многих случаях, социально-экономических преимуществ мужчин. В силу своего пола, гендера и возраста мужчины по-прежнему принадлежат к социальной группе, которая контролирует, а не контролируется. Подобный жест восхищения приобретает совершенно иное значение, нежели влюбленность поклонника-подростка. Другими словами, мужчина, идентифицирующий себя как фанат, просто играет роль без необходимости быть всем тем, что она собой символизирует, это акт потребительского косплея и, по сути, субкультурной инкорпорации (Hebdige, 1979, p. 94-95). Эти люди могут позволить себе «перенимать только модели поведения, не опасаясь последствий» (Miller, 2006, p.154). Они могут заниматься «фанатскими штучками» как любимым делом, не сталкиваясь с вышеупомянутыми последствиями патологического фанатства; быть фанатом - это просто деятельность, способ потребления и хобби. На самом деле стигматизация, которой подвергаются самчхон, кажется гораздо менее серьезной, чем та, которая ассоциируется с типичным фандомом в целом. Другими словами, их опыт общения с социальной структурой в корне отличается от опыта женщин или подростков, а значит - их приобретенные культурные предпочтения и вкусы должны значительно отличаться от вкусов последних.

В статье журнала Time о Crayon Pop (Rothman 2013) выражается опасение, что фанаты-мужчины «жутковаты», а модель фаната-самчхон служит для 
оправдания извращенного, квазипедофилического желания. Отсюда, возможно, именно культурная склонность рассматривать сексуальное влечение более взрослых мужчин к юным девушкам как табу заставила фаната Crayon Pop отрицать романтический аспект мужского интереса. Более того, использование для описания термина, связанного с родством («самчхон», т.е. «дядя»), только усугубляет неловкость ситуации. С учётом интерпретации любви фанатов как мужского желания контроля и подчинения, становится понятно, почему употребление термина из области семейных отношений может ассоциироваться с инцестом. Кажется, что использование этого термина самими мужчинами предполагает их бесстыдное чувство права обладать женщинами, в то время как его применение широкой публикой лишь показывает, насколько женоненавистнической является культура и насколько люди забывают о последствиях патриархального образа мышления, пронизывающего общество. Хотя очевидно, что происходит и осознание доминирующего мужского социального порядка, благодаря которому это преобразованное мужское желание так легко себя обнаруживает, оправдание и терпимость к такому систематизированному и внутренне укоренившемуся женоненавистничеству еще сохраняется и столь явно проявляется в индустрии развлечений.

Тем не менее, важно отметить, что привилегированное социальнополитическое положение мужчин в устойчивой патриархальной системе ценностей не делает явление самчхон сомнительным, пустым или незначительным. Стоит привести аргументы в пользу другой интерпретации этой версии фан-культуры и ее появления в различных формах СМИ как формы политического и культурного комментария к мужской и женоненавистнической социальной атмосфере. Как уже говорилось ранее, выбор фанатамимужчинами моделей потребления представляет собой намеренный отход молодых от образа жизни, установленного предыдущими поколениями. Финансовый кризис, охвативший многие азиатские страны в конце 1990-х годов, а также последовавшая вскоре разочаровывающая рецессия, возможно, способствовали возникновению у поколения после бэби-бума мысли о том, что унаследованная ими модель мужественности (в которой от мужчин ожидалось, что их жизнь будет сосредоточена в первую очередь вокруг работы и семьи, и в которой их успех в качестве отца и главы семьи был основой их авторитета), а также экономический и социальный мир, который зависел от нее, могут оказаться неустойчивыми. Серьезность ситуации наверняка ощущали и молодые, и пожилые. Во время финансового кризиса огромное количество корейских патриархов, оказавшихся безработными, банкротами или иным образом неспособными обеспечить свои семьи, предпочли скорее расстаться с жизнью, чем признать свою несостоятельность и столкнуться с последующим унижением. Дегуманизированные и низведенные до уровня безличных машин, зарабатывающих на жизнь, мужчины, возможно, также подверглись десексуализации во время общественных потрясений. 
Объясняя чувства поклонника Crayon Pop, можно заметить, что мужчины, смирившиеся с обесцениванием их самих и их сексуальности в условиях экономического бума, на самом деле могли рассматривать свое желание как сугубо несексуальное, в отличие от присущего мужчинам собственнического желания. Во любом случае, несколько социальных, экономических и политических факторов способствовали ощущению краха, разочарования и неудовлетворенности в южнокорейском обществе в конце 1990-х годов. В Корее и близлежащих регионах произошел ряд событий, которые, на мой взгляд, отвечают этим настроениям. Например, в одной только Южной Корее выпускники колледжей в возрасте 20-30 лет вновь проявили интерес к гуманитарным и социальным наукам, которые, казалось, оказались на задворках экономического и промышленного бума страны в послевоенные десятилетия (Harvie and Lee 2003). Все чаще встречается стремление к «чему-то большему», чем деньги и supek (от слова «спец», т.е. «спецификация», соотносящая человеческие качества с техническими характеристиками электронных изделий). В последние годы стремительно растет количество публичных лекций и семинаров по истории, философии и другим гуманитарным дисциплинам, проводимых частными, некоммерческие организациями, университетами, публичными библиотеками и местными органами власти.

Одной из таких компаний является сеульская Ddanzi Group, прогрессивно настроенная компания, выпускающая новостной веб-журнал под названием Ddanzi Ilbo / Daily Ddanzi (последнее слово - жаргонизм, отражающий самопровозглашенный «искривленный взгляд» на текущие политические события), а также ряд подкастов. Веб-Журнал стал центром общественных дебатов и просвещения, а также центробежной точкой прогрессивных голосов. Он начал свою работу в 1998 году как личный блог основателя Ким Уджуна, состоящий из сатирических комментариев к основным новостным СМИ. Компания до сих пор придерживается заметно прогрессивной позиции, устраивала интервью, лекции в месяцы подготовки к президентским выборам в декабре 2012 года. На этих мероприятиях выступали видные политики и политически активные деятели из прогрессивного лагеря (в центре которого находится оппозиционная Минчжодан, или Демократическая партия), включая законодателей Со Кихо, Чон Дон Ёна и Но Хючана, а также потенциальных кандидатов в президенты Ким Дуквана, Мун Джэина, Сон Хагю и Чон Секюна. В серии подкастов Naneun Ggomsuda / I Am a Trickster («Я - трикстер»), сатирически критикующей бывшего тогда президентом Ли Мён Бака, случайные слушатели узнали о коррупции и скандалах, окружавших президента и доминирующую консервативную партию (Choе 2013, А6). Однако компания также проводила публичные лекции журналистов, писателей и ученых, встречи книжного клуба раз в две недели, где обсуждались различные классические и современные произведения по философии, политологии, истории и религии в части офиса, превращенной в кофейню. Именно здесь общественное движение молодых корейцев (которое, как я подозреваю, подпитывает и, отчасти, проявляется в 
возникновении взрослых фанатов музыки К-рор) оказывается многогранным и в то же время отчетливо политическим. Несколько лекций и семинаров, которые я посетил летом 2012 года, полностью заполнили подвальное кафе вместимостью около 300 человек, а онлайн-трансляции мероприятий заинтересовали ещё больше слушателей. Среди значительного числа корейцев в возрасте 20-30 лет становится «круто» быть политически активным и широко осведомленным вне своей профессии.

Стремление получить всесторонние знания в области гуманитарных наук, политического активизма и других интересов не просто отвлекает от работы и семейной жизни, а помогает преодолеть замкнутое, некоммуникабельное и авторитарное мировоззрение, сформировавшееся у предыдущих поколений корейских мужчин. В этом смысле новые поклонники самчхон и то, что они воплощают, напоминают sôshokukei danshi («травоядных мужчин»), которые, по-видимому, впервые возникли в Японии. Термин «травоядный», введенный Маки Фукасавой, используется для описания «стройных гетеросексуальных мужчин, профессионально не амбициозных, склонных к потребительству, пассивных или не заинтересованных в гетеросексуальных романтических отношениях» (Charlebois, 2013, p. 89). Традиционный западный идеал маскулинности тесно связан с мясоедением на многих уровнях. Красное мясо, в частности, не только широко ассоциируется со здоровым мужским телом, но и символизирует «мужское господство над природой» (Potts and Parry 2010, р. 58), поскольку само мясо часто готовится со следами крови, которая во многих человеческих культурах понимается как сущность жизни и символ силы (Lévi-Strauss, 1970). В отличие от них, травоядные мужчины, которых, по оценкам, до 60 \% среди японских мужчин в возрасте приблизительно 20 лет, предпочитают проводить свободное время за занятиями вроде садоводства и вязания, что не ассоциируется с традиционными мужскими ролями и интересами (Garcia, 2008, p. xviii). Ученые связывают рост этих альтернативных маскулинностей с экономическим спадом, который страна переживает с 1990-х годов, что привело к неспокойному социальному климату и разочарованию в существующих идеалах, особенно среди молодежи (Garcia, 2008, p. хviii). Взрослые молодые мужчины «больше не довольствуются простым следованием гегемонным мужским идеалам, а активно ищут и используют эстетические стили и характеристики, условно ассоциируемые с женщинами, в своих собственных целях» (Iida 2005, р.59). Хотя очевидная «феминизация» мужских стилей и эстетических предпочтений может быть наиболее заметной чертой движения, оно, строго говоря, не связано с женоподобностью или гендерным эгалитаризмом. Шарлебуа пишет:

Располагаясь в меняющейся социальной географии Японии, травоядные маскулинности скорее обозначают контекст, в котором давно желанные и гегемонные мужские гендерные практики в настоящее время недоступны. В ответ на эту социокультурную ситуацию травоядная маскулинность представляет собой пастиш альтернативных гендерных практик, которые могут, 
но сами по себе не уравнивают отношения между мужчинами и женщинами, между маскулинностью и фемининностью $(2013$, р. 90)

Травоядная маскулинность, другими словами, знаменует собой отход от традиционного шаблона и того, что он обозначает, но, похоже, не определяет и не ограничивает направление или цель этой альтернативы. Скорее, их «деконструкция или разрушение жестких [...] гендерных категорий и образов» (Miller, 2006, p.151) в конечном итоге «нарушает стабильность гегемонного порядка и патриархального мужского “я"» (Iida, 2005, p. 69). Кажущийся эстетическим выбор мужчин, по своей сути, имеет отношение не только к гендерным стилям или способам самопрезентации как таковым, но и (что более важно) к социально-политическим вопросам, а также к гендерной и поколенческой политике.

\section{Быть мужчиной... который покупает}

Примечательной особенностью проявления этого движения в виде поклонников самчхон является то, что оно требует в качестве необходимого условия для функционирования потребительский, капиталистический общественный порядок. Иными словами, выражение альтернативного мировоззрения и системы ценностей предполагает демонстративное потребление товаров. Это отличается от констатации очевидного факта, что любой социальный комментарий на статус-кво обязательно зависит от последнего, чтобы иметь смысл или, возможно, вообще существовать. Политически заряженный посыл молодых корейцев воплощается в потребительской деятельности среднего класса, поскольку возможность посвятить время таким вторичными интересам, как посещение концертов, философских дискуссий и политических лекций, является роскошью, которая предполагает наличие основной работы с достаточно высокой заработной платой. Более того, в сфере индустрии популярной культуры роль мужчин как потребителей на рынке имеет гораздо более конкретные последствия, чем их гегемонное положение в обществе. Их роль как потребителей культурных артефактов, циркулирующих в СМИ, в отличие от администраторов телеканалов, руководителей управляющих компаний или знаменитостей, снимающихся в телепрограммах и музыкальных записях, наиболее четко отличает их от всех остальных. Поэтому зрители-мужчины, сидящие в телевизионной студии, могут смотреть на объект обожания совсем не так, как это делает телеведущий, берущий у нее интервью на сцене. Задача здесь не в том, чтобы осуждать одну (или обе) из этих манифестаций как откровенно хищное мужское стремление обладать объектом желания и одержимости. Резкое различие в объеме культурного капитала (и вообе капитала) фаната и знаменитости, в сочетании с нежеланием или неспособностью мужчин-фанатов бросить вызов потребительскому, капиталистическому порядку индустрии популярной культуры, который превращает в товар как объект желания, так и само желание, приводит к вышеупомянутому неравен- 
ству, делает неправдоподобным интерпретацию желания фаната просто как плохо замаскированной мужской тяги к доминированию.

В этом контексте изображение в СМИ феномена самчхон имеет сложные последствия для мужчин. В некотором смысле то, что они получили заметное освещение и внимание СМИ, является триумфом для мужчин, демонстрирующих и проявляющих альтернативные качества, которые могут бросить вызов гегемонному гендерному образу и идеалам. Это редкость, когда такое мощное послание распространяется через средства массовой информации, где обычно преобладает однообразие. И это особенно удивительно, если учесть, что именно соответствующие гегемонному социальному порядку мужчины (и получающие из него выгоду) контролируют индустрию развлечений Южной Кореи. Но не слишком ли это хорошо, чтобы быть правдой?

Изображение в СМИ альтернативных маскулинных качеств может в реальности сдерживать и смягчать мощное политическое послание. На первый взгляд, кажется странным, что индустрия развлечений обращается именно к этой демографической группе. Можно оправдывать любопытное расширение целевой аудитории, указывая на то, что сегодня индустрия имеет как никогда большое предложение исполнителей и песен, в то время как спрос остается ограниченным; но это кажется рискованным решением. С одной стороны, мужчины явно идут против широко принятых и разделяемых общественных идеалов в своей готовности потреблять товары популярной культуры и делать модель потребления частью своей конструируемой идентичности. С другой стороны, они слишком похожи на предыдущие поколения, что может способствовать восприятию обществом выбранных ими товаров как «некрутых». Однако растущий интерес и внимание СМИ к этим мужчинам на южнокорейском телевидении говорят о том, что рискованное решение, возможно, оказалось оправданным, а некогда угрожающий политический посыл, лежащий в основе их демонстративного потребления, возможно, утратил свою силу ставить под сомнение гендерные идеалы в существующей общественной норме. Тот факт, что все больше и больше мужчин эстетически дистанцируются от традиционной маскулинности аджосси, способствует восприятию этих мужчин как нестандартных и, в конечном счете, безобидных.

\section{Заключение}

Чрезвычайно важно, что взрослые фанаты-мужчины строят свои образы и способы самопрезентации, потребления товаров в зависимости от сформированного обществом типа, образца или габитуса. Их вкусы и предпочтения формируются под влиянием исторических и политических факторов, о чем говорилось выше, а их воздействие, в свою очередь, проявляется в социальных, экономических и политических тенденциях. Если учесть, что массовая медиация и ремедиация любого (разумно распространяемого и циркулирующего) политического сообщения неизбежна, если не необходима, для его даль- 
нейшего распространения, потенция того, что воплощают такие упомянутые примеры, как индустрия мужской красоты и фанаты самчхон (и их демонстративное потребление музыкальных товаров), не может быть полностью побеждена и уничтожена их интеграцией и изменением контекста.

Их появление, скорее, вывело альтернативные маскулинности и саму возможность их существования на южнокорейский социально-политический ландшафт для дальнейшего обсуждения и продвижения. К тому же, это привело к широкому распространению информации об альтернативных маскулинностях не только среди молодых мужчин-знаменитостей, которые, несомненно, эстетически восприимчивы, но могут казаться далекими и несколько обезличенными, но и среди обывателей, для которых нетрадиционная маскулинность может быть недоступна из-за давления общества в различных формах, вынуждающего соответствовать норме, в которой акцент на авторитете и легитимности серьезных, патриархальных мужских фигур, преданных работе и семейной жизни, определяет не только нормативную маскулинность, но и нормативную зрелость и взрослость. В частности, в случае с фанатами самчхон активное и очень заметное участие взрослых мужчин в фандоме представляет собой альтернативный способ потребления для данной демографической группы, и указывает на возможность гораздо более масштабного, сложного движения, бросающего вызов ранее существовавшим представлениям о мужественности и о том, что она должна подразумевать. Появление альтернативных маскулинностей и способов конструирования альтернативных субъектностей в социальной динамике Южной Кореи следует приветствовать, поскольку они будут способствовать обогащению культурных дискурсов, происходящих в стране, чей быстрый экономический и социальный рост во второй половине XX века сопровождался явным отсутствием культурного разнообразия и процветанием авторитарной, патриархальной власти вокруг нее.

\section{Список литературы / References}

All That Music. (2002). Seoul: MBC-FM4U.

Bourdieu, P. (1977). Outline of a Theory of Practice (NiceR., Trans.). Cambridge: Cambridge University Press.

Bourdieu, P. (1984). Distinction: A Social Critique of the Judgment of Taste. New York: Routledge.

Charlebois, J. (2013). Herbivore masculinity as an oppositional form of masculinity. Culture, Society E Masculinities, 5(1), 89-104.

Choe, S. (2013, May 12). South Korea Seeks Journalist's Arrest in Defamation Case. The New York Times. Retrieved from https://www.nytimes.com/2013/05/13/world/asia/south-korea-seeksarrest-of-podcaster-choo-chin-woo.html

Garcia, G. (2008). The Decline of Men: How the American Male Is Getting Axed, Giving Up, and Flipping Off His Future. New York: Harper Perennial. 
Harvie, C., \& Lee, H. (2003). Export-led industrialisation and growth: Korea's economic miracle, 19621989. Australian Economic History Review, 43(3), 256-286.

Hebdige, D. (1979). Subculture: The Meaning of Style. New York: Methuen.

Iida, Y. (2005). Beyond the 'feminization of masculinity': Transforming patriarchy with the 'feminine' in contemporary Japanese youth culture. Inter-Asia Cultural Studies, 6(1), 56-74. doi: $\underline{10.1080 / 1462394042000326905}$

Jenson, J. (1992). Fandom as pathology: The consequences of characterization. In L. Lewis (Ed.), The Adoring Audience: Fan Culture and Popular Media (pp. 9-29). London and New York: Routledge.

Lévi-Strauss, C. (1970). The Raw and the Cooked (J. Weightman \& D. Weightman, Trans.). New York: Harper \& Row.

Miller, L. (2006). Beauty Up: Exploring Contemporary Japanese Body Aesthetics. Berkeley, CA: University of California Press.

Ministry of Strategy and Finance. (2012). Current state of employment in Korea: Comparison of key indices to OECD (Organisation for Economic Co-operation and Development) member states. Retrieved from http://www.mosf.go.kr/news/news02.jsp?actionType=view\&runno=4014784

Pak, G. L. (2006). On the mimetic faculty: A critical study of the 1984 Ppongtchak debate and postcolonial mimesis. In K. Howard (Ed.), Korean Pop Music: Riding the Wave (pp. 62-71). Folkestone, Kent: Global Oriental.

Park, S. (2011). Yoo Hee-Yeol's Sketch Book [sic]: Four Keywords from Show's First Hundred Episodes. Retrieved from Ten Asia website: http://tenasia.hankyung.com/archives/7345

Pearson, J. (2012, May 29). What's with all these "Ladygates?" The Korea Times. Retrieved from http://www.koreatimes.co.kr/www/news/opinon/2012/05/137 111949.html

Potts, A., \& Parry, J. (2010). Vegan Sexuality: Challenging Heteronormative Masculinity through Meatfree Sex. Feminism \& Psychology, 20(1), 53-72. doi: $\underline{10.1177 / 0959353509351181}$

Rothman, L. (2013). K-Pop's unlikeliest fans: Middle-age males. Retrieved from Time Entertainment website: http://entertainment.time.com/2013/09/02/k-popsunlikeliest-fans-middle-agemales. Accessed 2 January 2014

Son, M. (2006). Regulating and Negotiating in T'ûrot'û, a Korean Popular Song Style. Asian Music, 37(1), $51-74$.

Yu Huiyeol's Sketchbook. (2009). Seoul: KBS-2TV.

Yu Huiyeol's Sketchbook. (2012). Seoul: KBS-2TV. 